\title{
Comparative Study of Rumen Ciliate Fauna of Goat and Sheep in Libya
}

\author{
Libya'daki Keçi ve Koyunların İşkembe Siliyat Faunasının Karşılaştırmalı \\ Çalışması
}

\author{
(1) Gözde Gürelli, (1) Asem Ramadan Amar Mohamed \\ Kastamonu University, Faculty of Sciences and Arts,Department of Biology, Kastamonu, Turkey
}

\author{
Cite this article as: Gürelli G, Mohamed ARA. Comparative Study of Rumen Ciliate Fauna of Goat and Sheep in Libya. \\ Turkiye Parazitol Derg 2021;45(4):274-9.
}

\begin{abstract}
Objective: This study aims to provide comparative information on the rumen ciliate fauna of goat (Capra aegagrus hircus) and sheep (Ovis aries) living in Zawiya, Libya.

Methods: We obtained rumen samples from 16 goats and 17 sheep after the slaughter in Zawiya, Libya between June and August 2016. We immediately fixed the well-mixed samples with an equal volume of $18.5 \%$ formalin. We filtered and stained the samples in the laboratory with methyl green formalin saline solution to determine the nuclei and added $2 \%$ Lugol's iodine solution to visualize the skeletal plates.

Results: We found that the mean number ( \pm standard deviation) of ciliates in the rumen contents from goats and sheep was $70.9 \pm 61.6 \times 10^{4}$ cells $\mathrm{mL}^{-1}$ (minimum-maximum value, $4.0-187.0 \times 10^{4}$ cells $\mathrm{mL}^{-1}$ ) and $96.3 \pm 49.3 \times 10^{4}$ cells $\mathrm{mL}^{-1}$ (minimummaximum value, $19.5-235.0 \times 10^{4}$ cells $\left.\mathrm{mL}^{-1}\right)$, respectively. Results also showed that the total number of species per goat and sheep

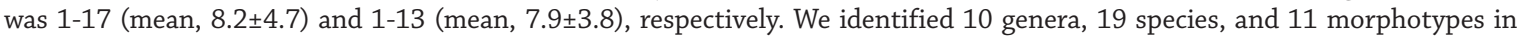
goats and 9 genera, 16 species, and 13 morphotypes in sheep. Additionally, we found that Entodinium simulans prevalence in all goats and sheep was $100 \%$. On the other hand, we observed Hsiungia triciliata and Ostracodinium gracile in only one goat (6.3\% prevalence) and Polyplastron multivesiculatum in only one sheep (5.9\% prevalence). Overall, the ruminal ciliate fauna of goat and sheep in Libya comprised Entodinium species (mean for goats, $85.9 \%$; mean for sheep, $83.5 \%$ ).

Conclusion: This study recorded Hsiungia triciliata as a new endosymbiont in goats. To our knowledge, this study is the first to report all of the species detected in goats from Libya. Similarly, this is the first to detect Diplodinium anisacanthum, Entodinium bursa, E. ellipsoideum, E. longinucleatum, E. simulans, Isotricha prostoma, Ophryoscolex caudatus, Ostracodinium gracile, and Polyplastron multivesiculatum in sheep from Libya.
\end{abstract}

Keywords: Ciliate, rumen, goat, sheep, Libya

ÖZ

Amaç: Bu çalışmanın amacı Zawiya, Libya'da bulunan keçilerin (Capra aegagrus hircus) ve koyunların (Ovis aries) işkembe siliyat faunası üzerine karşılaştırmalı bilgiler elde etmektir.

Yöntemler: İşsembe örnekleri Zawiya, Libya'daki 16 keçi ve 17 koyundan Haziran 2016 ve Ağustos 2016 tarihleri arasında kesim işlemlerinden hemen sonra alınmıştır. İyi karışmış örnekler eşit hacimli \%18,5'lik formalin ile hemen tespit edilmiştir. Örnekler laboratuvarda süzülmüş ve metil yeşili formalin salin solüsyonuyla boyanmıştır. Metil yeşili formalin salin solüsyonu nukleusları belli etmek için kullanılmış ve iskelet plaklarını belli etmek için de örneklere \%2'lik Lugol'ün iyot solüsyonu eklenmiştir.

Bulgular: Libya'daki 16 keçinin ve 17 koyunun işkembe örneklerindeki siliyat sayısı ( \pm standart sapma) sırasıyla, $70,9 \pm 61,6 \times 10^{4}$

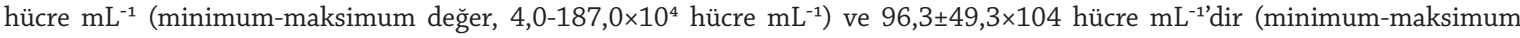

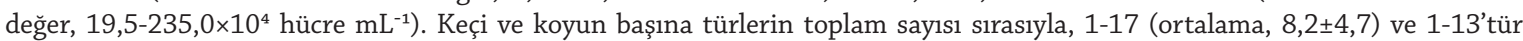

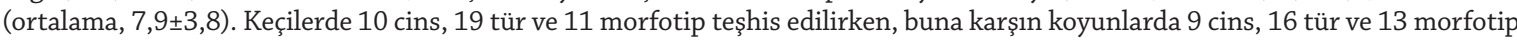
tespit edilmiştir. Entodinium simulans bütün keçilerde ve koyunlarda \%100'lük bir oranda tespit edilmiştir. Hsiungia triciliata ve Ostracodinium gracile sadece 1 keçide (\%6,3 yaygınlık), aynı şekilde Polyplastron multivesiculatum sadece 1 koyunda (\%5,9 yaygınlık) gözlemlenmiştir. Genelde, Libya'daki keçi ve koyunların işkembe siliyat faunası Entodinium türlerinden oluşmaktadır (keçiler için ortalama \%85,9; koyunlar için ortalama \%83,9).

Sonuç: Hsiungia triciliata, keçiler için yeni bir endosimbiyonttur. Keçilerden tespit edilen tüm türler, Libya'dan ilk kez rapor edilmiştir. Diplodinium anisacanthum, Entodinium bursa, E. ellipsoideum, E. longinucleatum, E. simulans, Isotricha prostoma, Ophryoscolex caudatus, Ostracodinium gracile ve Polyplastron multivesiculatum Libya'daki koyunlarda ilk kez tespit edilmiştir.

Anahtar Kelimeler: Siliyat, işkembe, keçi, koyun, Libya 


\section{INTRODUCTION}

The rumen is the main example of an extremely diverse, densely colonized microbial habitat, which contains bacteria, archaea, and protists (1). Rumen ciliated protozoa are the prime eukaryotic component of the rumen ecosystem and can contribute up to $50 \%$ of the biomass in the rumen (2). These symbiotic ciliates belong to the subclass Trichostomatia and can utilize a vast array of carbohydrate compounds, such as soluble sugar, starch, and lignocellulose $(3,4)$. Rumen ciliate species composition and concentration vary the type and amount of feed consumed, $\mathrm{pH}$, turnover rate, and frequency of feeding $(5,6)$. Trichostomatid ciliates are classified into two orders Vestibuliferida and Entodiniomorphida. Most of the rumen ciliates are composed of ophryoscolecid ciliates in the order Entodiniomorphida $(3,7,8)$. Despite the general morphology of ophryoscolecid ciliates shows a great uniformity, these ciliates have a monophyletic origin $(9,10)$. Transfaunation of rumen ciliates occurs only by direct contact of hosts throughout their lifetime (11).

Libya is in the African continent, and there has been no study on the rumen ciliates of goats living there. Therefore, the aim of this study to provide comparative information on the rumen ciliate fauna of goat (Capra aegagrus hircus) and sheep (Ovis aries) living in Zawiya, Libya.

\section{METHODS}

Rumen samples were obtained from 16 goats (C. aegagrus hircus) and 17 sheep (O. aries) after the slaughter in Zawiya, Libya between June 2016 and August 2016. The well-mixed samples were immediately fixed with an equal volume of $18.5 \%$ formalin (12). In the laboratory, they were filtered and stained with methyl green formalin saline (MFS) solution to get differential and total cell counts (13). The MFS solution was used to indicate nuclei and the solution of $2 \%$ Lugol's iodine was added to samples to visualize the skeletal plates $(14,15)$.

The mean number of ciliates in each goat and sheep was determined using the hemocytometer counting chamber. The relative abundances of ciliate species in each goat and sheep were estimated from smear slides $(16,17)$. The prevalence calculation of ciliate species was performed as previously described by Bush et al. (18).

The species were identified and classified based on previously published species descriptions and taxonomic lists $(8,13,19-21)$.

\section{Statistical Analysis}

Statistical analysis of rumen ciliates was performed by the SPSS statistics 20 programs.

\section{RESULTS}

The mean number ( \pm standard deviation) of ciliates in the rumen contents from the 16 goats and 17 sheep living in Libya was $70.9 \pm 61.6 \times 10^{4}$ cells $\mathrm{mL}^{-1}$ (minimum-maximum value, 4.0$187.0 \times 10^{4}$ cells $\mathrm{mL}^{-1}$ ) and $96.3 \pm 49.3 \times 10^{4}$ cells $\mathrm{mL}^{-1}$ (minimummaximum value, $19.52-35.0 \times 10^{4}$ cells $\mathrm{mL}^{-1}$ ), respectively. The total number of species per goat and sheep was 1-17 (mean, $8.2 \pm 4.7$ ) and $1-13$ (mean, $7.9 \pm 3.8$ ), respectively.

The relative abundance and the prevalence of genera and species in the rumen contents of goat and sheep in Libya are shown in
Table 1. In goat, 10 genera, 19 species, and 11 morphotypes were identified, whereas, in sheep, 9 genera, 16 species, and 13 morphotypes were detected. Entodinium simulans was found in all goats and sheep with a prevalence of $100 \%$. Hsiungia triciliata and Ostracodinium gracile were observed in only one goat $(6.3 \%$ prevalence), likewise, Polyplastron multivesiculatum was observed in only one sheep (5.9\% prevalence). In general, the ruminal ciliate fauna of goat and sheep in Libya was composed of Entodinium species (mean for goats, 85.9\%; mean for sheep, 83.5\%). $H$. triciliata is a new endosymbiont recorded for the goats. All of the species detected from the goats are the first report in Libya. Diplodinium anisacanthum, Entodinium bursa, E. ellipsoideum, E. longinucleatum, E. simulans, Isotricha prostoma, Ophryoscolex caudatus, $O$. gracile, and $P$. multivesiculatum are first detected from the sheep in Libya.

\section{DISCUSSION}

The present study is the first for the rumen ciliate fauna of goats and the second for the rumen ciliate fauna of sheep in Libya. The mean number of ciliates in the rumen contents of sheep living in Zawiya, Libya $\left(96.3 \pm 49.3 \times 10^{4}\right.$ cells $\left.\mathrm{mL}^{-1}\right)$ was less than that of sheep in Triple city, Libya $\left(220 \times 10^{4}\right.$ cells $\left.\mathrm{mL}^{-1}\right)$. The number of ciliate species in sheep living in Zawiya, Libya was higher than sheep living in Triple city, Libya (Table 2). These variations may be the differences in the kinds and amounts of food consumed, host animals, geographical location, or a combination of these factors $(15,22,23)$.

In the present study, 10 genera, 19 species, and 11 morphotypes were found in goats and 9 genera, 16 species, and 13 morphotypes were found in sheep. Although this is the first report on rumen ciliates of goat in Libya, no novel species were detected. However, Hsiungia triciliata is recorded for the first time as a new endosymbiont for goats. Before, $H$. triciliata was detected from the dromedary camels in Zawiya, Libya (24) and also reported from the camels in Triple city, Libya (25). In addition, $H$. triciliata was found from the dromedary camels and cattle in Tunisia (26). The goat may have obtained this ciliate from close contact with cattle or camels because $H$. triciliata was not detected from sheep. In the rumen contents of goats and sheep in Zawiya, Libya, Entodinium spp. were generally predominant, it may be feeding habits of goats and sheep. Although goats and sheep are the intermediate feeders, goats are browsers while sheep are grazers. Goats consume concentrate selection such as leaves and tree sprouts (27-29), whereas sheep eat mostly grass, herbaceous flowering plants, and forbs (30). Goats were fed on steppe shrubs and sheep were fed on mixed-grass steppes and meadows in Libya. Additionally, cereal grain straw (barley, oat, and wheat hay) is the dietary source of both animals. The rumen of the intermediate feeders may have environmental factors more favorable for the growth of Entodinium spp. than those of true browser and true grazer (31). If the host is fed a high concentrate ration, the composition ratio of Entodinium spp. and their total density become higher because Entodinium spp. grow rapidly (32). The starch is the principal source of energy for Entodinium spp. (33). The host species itself may exert some degree of control over the specific fauna in its rumen. The selecting of particular foods and the quantities consumed by different host species are important factors on the rumen ciliate fauna $(31,34)$. In addition, 


\begin{tabular}{|c|c|c|c|c|}
\hline \multirow[b]{2}{*}{ Genus/species/morphotype } & \multicolumn{2}{|l|}{ Goat } & \multicolumn{2}{|l|}{ Sheep } \\
\hline & $\begin{array}{l}\text { Prevalence } \\
(\%)\end{array}$ & $\begin{array}{l}\text { Relative abundance }(\%) \\
\text { mean } \pm \text { SD } \\
\text { (minimum-maximum value) }\end{array}$ & $\begin{array}{l}\text { Prevalence } \\
(\%)\end{array}$ & $\begin{array}{l}\text { Relative abundance }(\%) \\
\text { mean } \pm \text { SD } \\
\text { (minimum-maximum value) }\end{array}$ \\
\hline Dasytricha Schuberg, 1888 & 37.5 & $\begin{array}{l}1.7 \pm 2.9 \\
(0-9.4)\end{array}$ & 70.6 & $\begin{array}{l}2.0 \pm 1.9 \\
(0-7.2)\end{array}$ \\
\hline D. ruminantium Schuberg, 1888 & 37.5 & $\begin{array}{l}1.7 \pm 2.9 \\
(0-9.4)\end{array}$ & 70.6 & $\begin{array}{l}2.0 \pm 1.9 \\
(0-7.2)\end{array}$ \\
\hline Diplodinium Schuberg, 1888 & 12.5 & $\begin{array}{l}0.1 \pm 0.3 \\
(0-1.2)\end{array}$ & 47.1 & $\begin{array}{l}4.0 \pm 6.1 \\
(0-18.1)\end{array}$ \\
\hline D. anisacanthum Da Cunha, 1914 & 12.5 & $\begin{array}{l}0.1 \pm 0.3 \\
(0-1.2)\end{array}$ & 47.1 & $\begin{array}{l}4.0 \pm 6.1 \\
(0-18.1)\end{array}$ \\
\hline m. anacanthum Dogiel, 1927 & - & - & 35.3 & $\begin{array}{l}0.4 \pm 0.6 \\
(0-2.0)\end{array}$ \\
\hline m. anisacanthum Da Cunha, 1914 & 12.5 & $\begin{array}{l}0.1 \pm 0.2 \\
(0-0.9)\end{array}$ & 41.2 & $\begin{array}{l}1.0 \pm 1.8 \\
(0-5.7)\end{array}$ \\
\hline m. diacanthum Dogiel, 1927 & - & - & 35.3 & $\begin{array}{l}0.4 \pm 0.6 \\
(0-1.9)\end{array}$ \\
\hline m. monocanthum Dogiel, 1927 & 6.3 & $\begin{array}{l}<0.1 \pm<0.1 \\
(0-0.1)\end{array}$ & 35.3 & $\begin{array}{l}0.5 \pm 0.8 \\
(0-2.3)\end{array}$ \\
\hline m. pentacanthum Dogiel, 1927 & - & - & 41.2 & $\begin{array}{l}0.8 \pm 1.4 \\
(0-4.8)\end{array}$ \\
\hline m. tetracanthum Dogiel, 1927 & 6.3 & $\begin{array}{l}<0.1 \pm 0.1 \\
(0-0.2)\end{array}$ & 35.3 & $\begin{array}{l}0.4 \pm 0.8 \\
(0-2.7)\end{array}$ \\
\hline m. triacanthum Dogiel, 1927 & 6.3 & $\begin{array}{l}<0.1 \pm<0.1 \\
(0-0.1)\end{array}$ & 35.3 & $\begin{array}{l}0.3 \pm 0.6 \\
(0-2.1)\end{array}$ \\
\hline $\begin{array}{l}\text { Enoploplastron Kofoid and MacLennan, } \\
1932\end{array}$ & 25.0 & $\begin{array}{l}0.5 \pm 0.9 \\
(0-2.8)\end{array}$ & - & - \\
\hline E. triloricatum (Dogiel, 1925) & 25.0 & $\begin{array}{l}0.5 \pm 0.9 \\
(0-2.8)\end{array}$ & - & - \\
\hline Entodinium Stein, 1859 & 100 & $\begin{array}{l}85.9 \pm 6.8 \\
(78.3-100.0)\end{array}$ & 100 & $\begin{array}{l}83.5 \pm 11.8 \\
(62.2-100.0)\end{array}$ \\
\hline E. bursa Stein, 1858 & 18.8 & $\begin{array}{l}0.6 \pm 1.4 \\
(0-3.7)\end{array}$ & 41.2 & $\begin{array}{l}0.9 \pm 1.2 \\
(0-3.3)\end{array}$ \\
\hline E. dilobum (Dogiel, 1927) & 75.0 & $\begin{array}{l}7.1 \pm 7.9 \\
(0-28.3)\end{array}$ & 76.5 & $\begin{array}{l}6.6 \pm 6.9 \\
(0-24.7)\end{array}$ \\
\hline $\begin{array}{l}\text { E. ellipsoideum (Kofoid and MacLennan, } \\
\text { 1930) }\end{array}$ & 31.3 & $\begin{array}{l}11.1 \pm 27.3 \\
(0-100.0)\end{array}$ & 52.9 & $\begin{array}{l}3.4 \pm 3.5 \\
(0-8.1)\end{array}$ \\
\hline E. exiguum Dogiel, 1925 & 62.5 & $\begin{array}{l}8.9 \pm 8.3 \\
(0-23.7)\end{array}$ & 17.6 & $\begin{array}{l}1.9 \pm 4.7 \\
(0-17.4)\end{array}$ \\
\hline E. longinucleatum Dogiel, 1925 & 62.5 & $\begin{array}{l}10.8 \pm 21.0 \\
(0-83.0)\end{array}$ & 47.1 & $\begin{array}{l}3.9 \pm 4.4 \\
(0-10.6)\end{array}$ \\
\hline E. minimum Schuberg, 1888 & 50.0 & $\begin{array}{l}6.4 \pm 6.3 \\
(0-16.1)\end{array}$ & - & - \\
\hline E. nanellum Dogiel, 1923 & 68.8 & $\begin{array}{l}11.2 \pm 9.8 \\
(0-31.1)\end{array}$ & 76.5 & $\begin{array}{l}14.1 \pm 8.9 \\
(0-25.9)\end{array}$ \\
\hline $\begin{array}{l}\text { E. rectangulatum Kofoid and MacLennan, } \\
1930\end{array}$ & 12.5 & $\begin{array}{l}0.8 \pm 2.1 \\
(0-6.7)\end{array}$ & - & - \\
\hline $\begin{array}{l}\text { m. rectangulatum Kofoid and MacLennan, } \\
1930\end{array}$ & 12.5 & $\begin{array}{l}0.8 \pm 2.1 \\
(0-6.7)\end{array}$ & - & - \\
\hline E. simulans Lubinsky, 1957 & 81.3 & $\begin{array}{l}28.8 \pm 17.6 \\
(0-51.4)\end{array}$ & 100 & $\begin{array}{l}52.3 \pm 21.9 \\
(28.0-100.0)\end{array}$ \\
\hline
\end{tabular}




\begin{tabular}{|c|c|c|c|c|}
\hline m. dubardi Lubinsky, 1957 & 62.5 & $\begin{array}{l}12.5 \pm 11.9 \\
(0-32.1)\end{array}$ & 100 & $\begin{array}{l}36.7 \pm 17.7 \\
(15.0-76.9)\end{array}$ \\
\hline m. lobosospinosum Lubinsky, 1957 & 68.8 & $\begin{array}{l}5.2 \pm 4.5 \\
(0-15.4)\end{array}$ & 82.4 & $\begin{array}{l}5.2 \pm 3.5 \\
(0-12.2)\end{array}$ \\
\hline m. caudatum Lubinsky, 1957 & 81.3 & $\begin{array}{l}10.8 \pm 7.9 \\
(0-24.8)\end{array}$ & 94.1 & $\begin{array}{l}10.9 \pm 6.2 \\
(0-25.0)\end{array}$ \\
\hline Epidinium Crawley, 1923 & 56.3 & $\begin{array}{l}3.9 \pm 5.3 \\
(0-17.0)\end{array}$ & 70.6 & $\begin{array}{l}3.8 \pm 4.9 \\
(0-18.7)\end{array}$ \\
\hline E. ecaudatum (Fiorentini, 1889) & 56.3 & $\begin{array}{l}3.9 \pm 5.3 \\
(0-17.0)\end{array}$ & 70.6 & $\begin{array}{l}3.8 \pm 4.9 \\
(0-18.7)\end{array}$ \\
\hline m. ecaudatum (Fiorentini, 1889) & 18.8 & $\begin{array}{l}1.3 \pm 4.3 \\
(0-17.0)\end{array}$ & 58.8 & $\begin{array}{l}1.8 \pm 2.6 \\
(0-10.1)\end{array}$ \\
\hline m. caudatum (Fiorentini, 1889) & 50.0 & $\begin{array}{l}2.6 \pm 3.6 \\
(0-12.5)\end{array}$ & 70.6 & $\begin{array}{l}4.3 \pm 5.5 \\
(0-16.2)\end{array}$ \\
\hline Hsiungia (Hsiung, 1932) & 6.3 & $\begin{array}{l}0.7 \pm 2.8 \\
(0-11.3)\end{array}$ & - & - \\
\hline H. triciliata (Hsiung, 1932) & 6.3 & $\begin{array}{l}0.7 \pm 2.8 \\
(0-11.3)\end{array}$ & - & - \\
\hline Isotricha Stein, 1858 & 56.3 & $\begin{array}{l}3.0 \pm 4.0 \\
(0-11.8)\end{array}$ & 64.7 & $\begin{array}{l}2.5 \pm 3.3 \\
(0-10.4)\end{array}$ \\
\hline I. intestinalis Stein, 1858 & 50.0 & $\begin{array}{l}1.3 \pm 1.8 \\
(0-6.7)\end{array}$ & 29.4 & $\begin{array}{l}0.9 \pm 1.9 \\
(0-7.2)\end{array}$ \\
\hline I. prostoma Stein, 1858 & 43.8 & $\begin{array}{l}1.7 \pm 2.7 \\
(0-9.3)\end{array}$ & 58.8 & $\begin{array}{l}1.6 \pm 1.9 \\
(0-5.7)\end{array}$ \\
\hline $\begin{array}{l}\text { Metadinium Awerinzew and Mutafowa, } \\
1914\end{array}$ & - & - & 17.6 & $\begin{array}{l}0.1 \pm 0.3 \\
(0-1.2)\end{array}$ \\
\hline M. affine (Dogiel and Fedorowa, 1925) & - & - & 17.6 & $\begin{array}{l}0.1 \pm 0.3 \\
(0-1.2)\end{array}$ \\
\hline Ophryoscolex Stein, 1858 & 62.5 & $\begin{array}{l}2.4 \pm 2.4 \\
(0-7.0)\end{array}$ & 41.2 & $\begin{array}{l}0.6 \pm 1.0 \\
(0-3.4)\end{array}$ \\
\hline O. caudatus Eberlein, 1895 & 62.5 & $\begin{array}{l}2.4 \pm 2.4 \\
(0-7.0)\end{array}$ & 41.2 & $\begin{array}{l}0.6 \pm 1.0 \\
(0-3.4)\end{array}$ \\
\hline m. tricoronatus Dogiel, 1927 & 62.5 & $\begin{array}{l}2.4 \pm 2.4 \\
(0-7.0) \\
\end{array}$ & 41.2 & $\begin{array}{l}0.6 \pm 1.0 \\
(0-3.4)\end{array}$ \\
\hline Ostracodinium Dogiel, 1927 & 6.3 & $\begin{array}{l}<0.1 \pm<0.1 \\
(0-0.1)\end{array}$ & 35.3 & $\begin{array}{l}0.9 \pm 1.3 \\
(0-3.5)\end{array}$ \\
\hline O. gracile (Dogiel, 1925) & 6.3 & $\begin{array}{l}<0.1 \pm<0.1 \\
(0-0.1)\end{array}$ & 35.3 & $\begin{array}{l}0.9 \pm 1.3 \\
(0-3.5)\end{array}$ \\
\hline Polyplastron Dogiel, 1927 & 50.0 & $\begin{array}{l}1.8 \pm 2.0 \\
(0-5.0)\end{array}$ & 5.9 & $\begin{array}{l}0.2 \pm 0.8 \\
(0-3.2)\end{array}$ \\
\hline $\begin{array}{l}\text { P. multivesiculatum (Dogiel and Fedorowa, } \\
\text { 1923) }\end{array}$ & 50.0 & $\begin{array}{l}1.8 \pm 2.0 \\
(0-5.0)\end{array}$ & 5.9 & $\begin{array}{l}0.2 \pm 0.8 \\
(0-3.2)\end{array}$ \\
\hline $\begin{array}{l}\text { Total species, morphotypes, and genera } \\
\text { number: }\end{array}$ & \multicolumn{2}{|c|}{19,11 , and 10} & \multicolumn{2}{|c|}{16,13 , and 9} \\
\hline \multicolumn{5}{|l|}{ SD: Standard deviation } \\
\hline
\end{tabular}

Entodinium spp. are normally predominant in the rumen and have a wide distribution in almost all ruminants, worldwide $(35,36)$.

Of the ciliate species detected from the goats and sheep, Entodinium simulans was the most abundant (100\%), it may be the wide distribution of E. simulans or the diet of the host. In the present study, $H$. triciliata and Ostracodinium gracile were reported only in one goat, likewise, Polyplastron multivesiculatum was found only in one sheep. These ciliates could have had rare opportunities for transmission between hosts, resulting in very limited distribution. In goat and sheep, Diplodinium, Epidinium, Ophryoscolex, Ostracodinium, and Polyplastron were observed.
Although Metadinium is present in goats, it was not reported from sheep, whereas Enoploplastron is present in sheep, it was not observed from goats. The species of genera Diplodinium, Epidinium, Ophryoscolex, Ostracodinium, Polyplastron, Metadinium, and Enoploplastron would be favorable for host animals fed mainly fresh and dried grass with low nutritive value (37). These ciliates have been considered to possess the cellulolytic activity and ingest many fragments of plants $(21,32,36,38)$.

In Libyan goats, the density of E. simulans morphotype with caudal spines is high, conversely, the density of E. simulans without caudal spines is high in Libyan sheep. When the hosts are 
Table 2. Total ciliate number and distribution of the total number of genera, species, and morphotypes of ciliates from the rumen contents of sheep in Libya

\begin{tabular}{|c|c|c|c|c|c|c|c|}
\hline $\begin{array}{l}\text { Host and } \\
\text { locality }\end{array}$ & $\begin{array}{l}\text { Mean ciliate } \\
\text { number }^{\mathrm{a}} \\
\left(\times 10^{4}{\left.\text { cells } \mathrm{mL}^{-1}\right)}\right.\end{array}$ & $\begin{array}{l}\text { Minimum- } \\
\text { maximum value of } \\
\text { ciliate number } \\
\left(\times 10^{4} \text { cells } \mathbf{~ m L}^{-1}\right)\end{array}$ & $\begin{array}{l}\text { Total } \\
\text { number } \\
\text { of genera }\end{array}$ & $\begin{array}{l}\text { Total } \\
\text { number } \\
\text { of species }\end{array}$ & $\begin{array}{l}\text { Total number } \\
\text { of } \\
\text { morphotypes }\end{array}$ & $\begin{array}{l}\text { Number } \\
\text { of animals } \\
\text { studied }\end{array}$ & References \\
\hline $\begin{array}{l}\text { Sheep, Triple city, } \\
\text { Libya }\end{array}$ & $220^{\mathrm{d}}$ & $180-280$ & 5 & 14 & 5 & 9 & (25) \\
\hline $\begin{array}{l}\text { Sheep, Zawiya, } \\
\text { Libya }\end{array}$ & $96.3 \pm 49.3$ & $19.5-235.0$ & 9 & 16 & 13 & 17 & Present study \\
\hline
\end{tabular}

fed a diet with low starch value, ciliates without caudal spines are predominant, whereas ciliates with well-developed caudal spines become predominant when the hosts are fed a diet with rich starch (39). It is considered that the caudal spines of Entodinium and Epidinium served to protect against engulfment of Entodinium bursa and P. multivesiculatum, respectively (40) because they are larger and carnivorous ciliates. However, the exact reason of spine development is not known. The rumen ciliate fauna of a goat and a sheep in Libya is composed of only Entodinium spp. It could be that Entodinium only fauna is the result of an extremely low $\mathrm{pH}$, a rapid rate of passage of fluid and particulate matter through the rumen, ingestion of specific toxic or inhibitory substances, or a combination of all these factors $(32,41-43)$ but it is not confirmed. Rumen ciliate populations of ruminants have been grouped into four main types $(13,21,44-46)$. All four groups include the genera Entodinium, Dasytricha, and Isotricha but are differentiated from each other based on the presence or absence of specific species. The A-type ciliate population is designated having P. multivesiculatum and usually, but not always, Metadinium affine. The B-type ciliate population contains Epidinium sp., Eudiplodinium maggii, or both. The K-type ciliate population is found in cattle populations containing Elytroplastron bubali. The O-type ciliate population includes only Entodinium, Dasytricha, and Isotricha. The A-type ciliate population and B-type ciliate are not present in the same host, because the predatory activity of $P$. multivesiculatum can eliminate E. maggii and Epidinium spp. Six of the 16 Libyan goats had the B-type, the remaining five and two of ten were the A-type and, the O-type, respectively. The remaining three goats contained the ciliates of the A-type and B-type together. Twelve of the 17 Libyan sheep had the B-type, the remaining four of the five were the O-type and the other one was the A-type. Besides, seven of seventeen sheep had Epidinium ecaudatum and Ophryoscolex together. Eadie (47) reported that it was not possible to establish Epidinium and Ophryoscolex in the same host. In the present study, the occurring of two species and the A-type and B-type population together in the same host indicate that these animals can live in the same area and they have many opportunities for cross-infection to each other.

\section{CONCLUSION}

Geographical distribution, phylogenetic factors, and feeding habits of the host species, $\mathrm{PH}$ in the rumen, antagonism, and transfaunation among the ciliate species have significant effects on the occurring rumen ciliate fauna.

\section{* Ethics}

Ethics Committee Approval: It is not necessary.
Informed Consent: It is not necessary.

Peer-review: Internally peer-reviewed.

\section{* Authorship Contributions}

Concept: G.G., Design: G.G., Data Collection or Processing: G.G., A.R.A.M., Analysis or Interpretation: G.G., Literature Search: G.G., Writing: G.G.

Conflict of Interest: No conflict of interest was declared by the authors.

Financial Disclosure: The authors declared that this study received no financial support.

\section{REFERENCES}

1. Solomon R, Jami E. Rumen protozoa: from background actors to featured role in microbiome research. Environ Microbiol Rep 2021; 13: 45-9.

2. Newbold CJ, Ramos-Morales E. Review: Ruminal microbiome and microbial metabolome: effects of diet and ruminant host. Animal 2020; 14: s78-s86.

3. Dehority BA. Protozoa of the digestive tract of herbivorous mammals. Insect Sci Appl 1986; 7: 279-96.

4. Mizrahi I. Rumen Symbioses. In: Rosenberg E, DeLong EF, Lory S, Stackebrandt E, Thompson F, editors. The Prokaryotes-Prokaryotic Biology and Symbiotic Associations. Berlin Heidelberg: Springer-Verlag; 2013. p. 533-44.

5. Dehority BA. Specificity of rumen ciliate protozoa in cattle and sheep. J Protozool 1978; 25: 509-13.

6. Franzolin R, Dehority BA. Effect of prolonged high-concentrate feeding on ruminal protozoa concentrations. J Anim Sci 1996; 74: 2803-9.

7. Imai S. Phylogenetic taxonomy of rumen ciliate protozoa based on their morphology and distribution. J Appl Anim Res 1998; 13: 17-36.

8. Lynn DH. The ciliated protozoa: characterization, classification, and guide to the literature. Dordrecht: Springer; 2008.

9. Dogiel VA. The phylogeny of the stomach infusorians of ruminants in the light of paleontological and parasitological data. Quart. J Microscop Sci 1947; 88: 337-43.

10. Vd'ačný P. Evolutionary associations of endosymbiotic ciliates shed light on the timing of the marsupial-placental split. Mol Biol Evol 2018; 35: 1757-69.

11. Moon-van der Staay SY, van der Staay GW, Michalowski T, Jouany JP, Pristas P, Javorský P, et al. The symbiotic intestinal ciliates and the evolution of their hosts. Eur J Protistol 2014; 50: 166-73.

12. Dehority BA. Evaluation of subsampling and fixation procedures used for counting rumen protozoa. Appl Environ Microbiol 1984; 48: 182-5.

13. Ogimoto K, Imai S, editors. Atlas of rumen microbiology. Tokyo: Japan Scientific Societies Press; 1981

14. Gürelli G. Rumen ciliate fauna (Ciliophora, Protista) of Turkish domestic goats living in İzmir, Turkey. Turk J Zool 2014; 38: 136-43. 
15. Gürelli G. Rumen ciliates of domestic cattle (Bos taurus taurus) in Kastamonu, Turkey, with the description of a new species. Eur J Protistol 2016; 56: 51-9.

16. Gürelli G. Rumen ciliate fauna of domestic sheep (Ovis aries) in İzmir, Turkey and scanning electron microscopic observations. Zootaxa 2017; 4286: 545-54.

17. Gürelli G, Yürücüoğlu N. Ruminal ciliate diversity of domestic cattle in Antalya, Turkey, with special emphasis on morphology of Entodinium rostratum (Entodiniomorphida, Ophryoscolecidae). Protistol 2019; 13: 71-8.

18. Bush AO, Lafferty KD, Lotz JM, Shostak AW. Parasitology meets ecology on its own terms: Margolis et al. revisited. J Parasitol 1997; 83: 575-83.

19. Dogiel VA. Monographie der familie Ophryoscolecidae. Arch Protistenkd 1927; 59: 1-288.

20. Dehority BA. Laboratory manual for classification and morphology of rumen ciliate protozoa. Florida: CRC Press; 1993.

21. Williams AG, Coleman GS, editors. The rumen protozoa. New York: Springer; 1992.

22. Imai S, Han SS, Cheng KJ, Kudo H. Composition of the rumen ciliate population in experimental herds of cattle and sheep in Lethbridge, Alberta, Western Canada. Can J Microbiol 1989; 35: 686-90.

23. Ito A, Imai S. Ciliated protozoa in the rumen of Holstein-Friesian cattle (Bos taurus taurus) in Hokkaido, Japan, with the description of two new species. Zool Sci 1990; 7: 449-58.

24. Gürelli G, Mohamed ARA. Ciliated Protozoan fauna in the forestomach of dromedary Camels (Camelus dromedarius) in Libya. Zootaxa 2018; 4434: 429-40.

25. Selim HM, Imai S, el Sheik AK, Attia H, Okamoto E, Miyagawa E, et al. Rumen ciliate protozoal fauna of native sheep, friesian cattle and dromedary camel in Libya. J Vet Med Sci 1999; 61: 303-5.

26. Gürelli G, Daw AFOE. Endosymbiotic ciliated protozoan biota of dromedary camels and domestic cattle in Tunisia. Zootaxa 2020; 4859: zootaxa.4859.3.6.

27. Ito A, Imai S, Manda M, Ogimoto K. Rumen ciliates of Tokara native goat in Kagoshima, Japan. J Vet Med Sci 1995; 57: 355-7.

28. Gurung YB, Parajuli N, Miyazaki Y, Imai S, Kobayashi K. Rumen ciliate faunae of water buffalo (Bubalus bubalis) and goat (Capra hircus) in Nepal. J Vet Med Sci 2002; 64: 265-7.

29. Cannas A, Pulina G. Dairy goats feeding and nutrition. Wallingford: $C A B$ International; 2008.

30. Burritt E, Frost R. Chapter 2: Animal behaviour principles and practices. In: Launchbaugh KL, Walker JW, Daines RJ, editors. Targeted Grazing: A Natural Approach to Vegetation Management and Landscape Enhancement. Englewood: American Sheep Industry Association; 2006. p. 10-21.

31. Ito A, Imai S, Ogimoto K. Rumen ciliates of ezo deer (Cervus nippon yesoensis) with the morphological comparison with those of cattle. J Vet Med Sci 1993; 55: 93-8.
32. Hungate RE. The rumen and its microbes. New York: Academic Press; 1996.

33. Kurihara Y, Takechi T, Shibata F. Relationship between bacteria and ciliate protozoa in the rumen of sheep fed on a purified diet. J Agric Sci Camb 1978; 90: 373-81.

34. Dehority BA. Rumen ciliate fauna of Alaskan moose (Alces americana), musk-ox (Ovibos moschatus) and Dall moutain sheep (Ovis dalli). J Protozool 1974; 21: 26-32.

35. Gürelli G, Canbulat S, Aldayarov N, Dehority BA. Rumen ciliate protozoa of domestic sheep (Ovis aries) and goat (Capra aegagrus hircus) in Kyrgyzstan. FEMS Microbiol Lett 2016; 363: fnw028.

36. Imai S. Ciliate protozoa in the rumen of Kenyan zebu cattle, Bos taurus indicus, with the description of four new species. J Protozool 1988; 35: 130-6.

37. Guirong, Su NR, Hua ZX, Zhu S, Imai S. Rumen ciliated protozoan fauna of the yak (Bos grunniens) in China with the description of Entodinium monuo n. sp. J Eukaryot Microbiol 2000; 47: 178-82.

38. Michalowski T, Belżecki G, Kwiatkowska E, Pejak JJ. The effect of selected rumen fauna on fibrolytic enzyme activities, bacterial mass, fiber disappearance and fermentation pattern in sheep. J Anim Feed Sci 2003; 12: $45-64$.

39. Lubinsky G. Studies on the evolution of Ophryoscolecidae. I. A new species of Entodinium with 'caudatum', 'lobosospinosum' and 'dubardi' forms and others. Can J Zool 1957; 35: 111-33.

40. Coleman GS, Laurie JI, Bailey JE. The cultivation of the rumen ciliate Entodinium bursa in the presence of Entodinium caudatum. J Gen Microbiol 1977; 101: 253-8.

41. Wilkinson RC, Van Hoven W. Rumen ciliate fauna of the springbok (Antidorcas marsupialis) in southern Africa. Zool Afr 1976; 11: 1-22.

42. Dehority BA. Rumen ciliate protozoa in Ohio white-tailed deer (Odocoileus virginianus). J Protozool 1990; 37: 473-5.

43. Dehority BA. Rumen ciliates of the pronghorn antelope (Antilocapra americana), mule deer (Odocoileus hemionus), white-tailed deer (Odocoileus virgianus) and elk (Cervus canadensis) in the Northwestern United States. Arch Protistenkd 1995; 146: 29-36.

44. Eadie JM. The development of rumen microbial populations in lambs and calves under various conditions of management. J Gen Microbiol 1962; 29: 563-78.

45. Imai S, Katsuno M, Ogimoto K. Distribution of rumen ciliate protozoa in cattle, sheep and goat and experimental transfaunation of them. Jpn J Zootech Sci 1978; 49: 494-505.

46. Imai S, Katsuno M, Ogimoto K. Type of the pattern of the rumen ciliate composition of the domestic ruminants and the predator-prey interaction of ciliates. Jpn J Zootech Sci 1979; 50: 79-87.

47. Eadie JM. Studies on the ecology of certain rumen ciliate protozoa. J Gen Microbiol 1967; 49: 175-94. 